\title{
Culinary discourse: Organic food in Estonia ${ }^{1}$
}

\author{
Eve Annuk
}

\begin{abstract}
Culinary discourse has become very visible in Estonian media in the recent years. The culinary theme has been present almost everywhere: in newspapers, women's magazines, TV and the Internet. One may describe it as an ever present feature of Estonian media. What to eat, how to cook both delicious and healthy food, cooking as creative experience - these are the main culinary topics.

There is also a relatively new discourse about organic food and its advantages over everyday food in Estonia. This is accompanied by a growing production of organic goods by Estonian farmers. Organic goods have also become visible in large supermarkets where they have acquired more space than before. Although the real quantities of organic production are quite small in comparison with the production of traditional agricultural products, the topic as such is not as marginal as it used to be some years ago.

In my paper I will deal with the following questions: Why has the culinary discourse acquired such an important role in Estonian media? What precisely are its roles and functions? How has organic food been presented in this context and what kind of values have been associated with it? Since food and cooking are also a cultural phenomenon, they are connected to identity. Therefore, I will analyse the discourse of organic food as a part of the true Estonian identity.
\end{abstract}

Keywords: organic food, media, food additives, identity

This article concerns the issue of cooking and organic food as represented in the Estonian media. Since my research is yet in an early stage, the article represents a pilot study identifying central research questions and defining the research field. The importance of the research topic itself arises from the fact that present day media are saturated with culinary issues and therefore it is important to understand the role of media discourse in creating and maintaining the perceptions of different aspects of food as well as to analyse the significance given to food in the media.

1 The article was written with the support of targeted research project 'Sources of Cultural History and Contexts of Literature' SF0030065s08. 
I will begin my analysis about culinary discourse with an example from my everyday life. About every two weeks, I receive a message in my institutional mailing list that outside our building at the main entrance of the Estonian Literary Museum it is possible to buy smoked or fresh fish and also fish products directly from a fisherman. Many of my colleagues and I will then go outside and buy his produce, which is tastier and also cheaper than in the market or shop. In the summertime, it is also possible to buy strawberries and tomatoes from him. Sometimes we can buy honey from an acquaintance of our colleague.

These non-official food networks have existed for years - as long as I remember. The word 'non-official' here means buying food products directly from the producer, without any mediators. Buying goods in this way also means not supporting big international food companies but our own very small Estonian producers. This attitude is shared by the advocates of organic food - they buy directly from farmers who are more likely to produce food which is unspoiled (without artificial additives, etc.).

My second example is from the Estonian media: during the period when I was preparing my article (October 2011), a large campaign about additives in food products was launched in the Estonian media (both in printed media and on the Internet). Although officially it was presented as an educational project concerning food additives (since not all of them are thoroughly "bad" or unhealthy), behind this seemingly neutral idea one could actually notice the interests of big food producing companies who wanted to defend their rights to add whatever they want into their food products. The campaign was rather onesided, representing all food additives as necessary and safe, at the same time hiding the real reasons for using them - the need of producers to get more profit.

These examples show that the issue of organic food is not something very "special" but that it is connected to our everyday reality in very tangible ways. Also, media are important in this discussion since media representations of food, culinary discourse and organic food contribute to this reality. 


\section{Culinary discourse and the media}

Culinary issues should be put in the larger social and cultural context: first of all, they are connected to the economic success of the country and its level of poverty, e.g. the proportion of people who are not able to buy enough food for themselves and their families. Secondly, we should consider the "national" cultural traditions of preparing food. In a similar way, food and cooking are constantly represented and constructed in media discourses.

The role of media in representing culinary discourse is remarkable. For example, cooking food is an everyday phenomenon on Estonian television as it is a regular part of the morning programme. Food, food products, and cooking recipes are considered important issues also in daily newspapers, women's magazines, internet portals. Besides, in the recent years a huge number of cookbooks have been published which also indicate the importance of the issue.

There is one very important person whose contribution to local food discourse is remarkable: Evelin Ilves, the wife of the president of Estonia. She is an avid propagator of organic food. Her most well-known achievement is raising the quality of the candies produced by the Estonian chocolate factory Kalev. She fought against adding hydrogenated vegetable fats in the chocolates produced by the factory, and a year after she had expressed her opinion on the matter in the media, Kalev discontinued using these in the most parts of its production lines.

Analysing the culinary discourse in the $19^{\text {th }}$ century France, researcher Priscilla Ferguson has argued that "Culinary discourse controls consumption, which it transforms into an intellectual activity” (Ferguson 2001: 31). Contextualising her claims, one can say that this is one of the reasons why culinary discourse has acquired such an importance in Estonia. Representing food and cooking in the media contributes to the increase of consuming more different food products. Representing cooking as an intellectual activity helps among other things to create the need for more unusual (and of course more expensive) foods (as for example truffles).

Besides the control of consumption, food talk carries other serious meanings. Researcher Marianne Lien has claimed in the book "The politics of food" (2004) that food is politicised due to its pollution: "Food is no longer simply a much needed material resource; its purchase is now linked to the need for consumers to balance monetary concerns with issues of risk and distrust [...] Food is politicised, not only as a commodity for consumption, but all the way into the kitchen and the dinner table, with implications for cooking and family care" (Lien 2004: 3). She argues that "the politics of food is no longer confined to policy-making within the nation-state, but closely connected to innovations 
and discourses that take place on the transnational arenas of science, technology and trade" (Lien 2004: 4).

This means that food is connected to power and control, to the issues of who has the privilege of talking about food, in which way, when and why, and what will remain unspoken. For example, the recent campaign in Estonian media about food additives (in autumn 2011) posed a central question "Are food additives harmful?", instead of questioning their necessity for human body. In this rhetorical way the campaign succeeded in hiding the real reason food additives are used, which actually is profit.

Culinary discourse also has its limits as there are issues which are not talked about. For example, although cooking food is an everyday phenomenon, money is almost never spoken about. TV chefs hardly pay any attention to the prices of the food products they use for their recipes. Also in printed media - in newspapers and women's magazines - the price of food products in culinary recipes is rarely addressed.

\section{What is organic food?}

Together with the growing importance of culinary discourse there has also been a growing awareness of the food itself: how much of it is pre-processed in food industry, which additives are present in our everyday food, etc. This situation has created a demand for food which is healthier and more likely to diminish health risks (for example being GMO-free, i.e. not containing genetically modified organisms) as it has been grown naturally. Production of organic food is also connected to the protection of the environment. Together with the growing production of organic food, a new media discourse has emerged: the discourse of organic food. This has become more important and visible in Estonian media in the last decade.

There are multiple terms designating organic food in Estonian: mahe ('mild'), orgaaniline ('organic'), ökoloogiline ('ecological'). The law about the organic agriculture (the first one coming into force in 1997) established the use of the term mahe.

Organic food is grown according to the principles of organic farming. The use of artificial fertilizers, pesticides, and other chemicals is prohibited. Raw material used in production (including the seeds) has to be controlled and also the whole growing process is under strict control. Once a year the controllers take samples for analyses. Also the use of GMO-s has been strictly prohibited. 
For getting the label of an organic product, the producers have to follow these strict rules and to be subjected to regular control.

In cattle-breeding, ecological farming values animal welfare. The use of hormones and antibiotics is not allowed. Besides, the conditions of cattle-breeding are strictly regulated: the cows have to have access to outdoor areas and feed on organic fodder. Therefore, those cows are sometimes called "happy cows" since they live in natural environment and in a natural way (Mahepõllumajandus Eestis 2012).

In general, there are principles which characterise organic farming: natural balance has to be taken into consideration in production; we must keep in mind that balanced substance circulation is not harmful to environment; organic food cannot contain harmful substances.

From the beginning of 1990 s, organic production and market have been growing rapidly both in Europe and in the world as a whole. The same can be said about Estonia where organically cultivated land was about $14 \%$ of all agricultural land in use by 2011 (ibid.)

\section{Organic food and the media}

Due to the rules regulating the production, organic food is more expensive than traditional agricultural products coming from those farms that practice intensive farming. That also means that the price of organic products in supermarkets is higher in comparison with the products of traditional agriculture, which sets limits to its consumption.

Since organic food has recently become an increasing important part of Estonian agriculture, it is reflected also in the media. The discourse of organic food is increasingly present too. The issue of organic food has been represented both in printed media and in the Internet news portals, in small announcements as well as in more elaborated articles dealing with the different aspects of organic food and organic farming. One can say that organic food has become an everyday issue in the Estonian media.

One of the most frequent themes dealt with in connection with organic food in Estonian media are the pros and cons of organic food in comparison with conventional food. Recently, in September 2012, a piece of news was published about the international study conducted by Stanford University which claimed that there is actually no difference between organic food and conventional food. Although the study was financed by a giant corporation Cargill in cooperation with some other large manufacturers who were obviously interested in discredit- 
ing the organic production, the Estonian media did not mention this important aspect of the research report.

Estonian media frequently discusses the prices of organic food in supermarkets. For example, a news text from February 2012 claimed that organic food is too expensive for Estonians, concluding that only two percent of people are willing to buy it (Ninn 2012).

Media are also concerned with many other topics connected to organic food such as where to buy ecological goods, which farmers grow organic products, or which food communities (food cooperations) organise the local sale of these products such as the community called Tagurpidilavka (http://tagurpidilavka. wordpress.com/author/tagurpidilavka/).

There are also special homepages on the Internet which are dedicated to issues of organic food and to the protection of environment (e.g. www.maheklubi. ee; www.bioneer.ee). Maheklubi.ee deals with every aspect of organic food and its production. It features articles about organic agriculture, laws that govern it, scientific research, news, etc. It provides information about where to buy organic food. The homepage is designed for the producers and consumers of organic food alike and therefore the information provided there is all-embracing. Bioneer.ee is an internet portal of "green lifestyle" dedicated to promoting environmental awareness and sustainable consumption. The information provided by this homepage covers every aspect of protecting the environment, including organic food, its production and scientific research concerning it.

How then does media construct the image of organic food and what kind of image do media represent? Marta Piigli who has studied the image of organic agriculture in the Estonian media found that in general the image of organic agriculture in Estonia is positive (Piigli 2007: 49). Based on her research, one can conclude that probably also the image of organic food is positive, although there is no actual research on this issue.

However, media practices concerning this issue can be characterised as diverse and sometimes contradictory. The researcher Stewart Lockie has described how the image of organic food is constructed in mass media. Often it is constructed in terms of what it is not (e.g. organic food is not the product of industrialised agriculture) but there may also be other connotations to the notion, e.g. organic food as a safe and natural alternative to conventionally grown food, or as a solution to environmental problems caused by conventional farming (Lockie 2006: 319).

This kind of understanding of organic food is noticeable also in the Estonian media. Organic food has sometimes been represented as antithetical to regular food: unspoiled, not containing food additives, with no traces of fertilizers 
and herbicides/pesticides, not destroying the balance of nature, not harmful to the human body, etc. Also the production of organic food is presented as environment-friendly since farmers do not use chemicals but instead make use of natural methods of fertilisation and pest control. The living conditions of livestock are not only environment-friendly, but also animal-friendly. As such, organic food is considered better than regular food which we usually buy from supermarkets.

On the other hand, one can sometimes find media articles where the author has questioned the superiority of organic food, giving the impression that the consumption of organic food is more a temporary trend than a necessity dictated by more profound reasons (Pullerits 2011).

\section{Food and identity}

Food is connected to identity (see also Żarski 2013, this volume, for an elaboration on this statement). People define themselves, among other things, through what they eat (as for example Jewish people consider kosher food as part of their identity). Every nation favours its traditional food and cooking.

The Estonian discourse of organic food is also connected to national identity. Organic food may be perceived as an aspect of being a true Estonian, which is connected to the love for Estonian nature and the traditional lifestyle in the countryside. Therefore, eating organic food is not only the matter of one's health, even though this is certainly the most important aspect of organic food. The way organic food is perceived defines also the identity of its consumers and their lifestyle. Since organic food is perceived as more natural and pure by its consumers, they define themselves as followers of a more natural lifestyle, being closer to nature and their Estonian roots. It affects not only the eating habits but also other choices connected to the lifestyle of those who opt for organic food. This may include, for example, using products which are recyclable and made of natural materials (such as clothes, household goods, furniture, building materials) and which are preferably of local origin (e.g. food which is produced by local farmers). Supporting the local producers also means supporting the traditional Estonian identity.

Estonian food communities whose lifestyle is based on the exchange of organic food products (for example delivering those products to each other) are called 'food coops' (toidu koopid): the idea is adapted from Germany where such food communities are rather common. These communities are also trying to show an alternative to the Western lifestyle which is known for exessive 
consumption. The members of the food communities define their lifestyles as environment-friendly. Media contributes to popularising these communities to the wider public by providing an overview of their activities and sharing their contact information (e.g. Sarjas 2012). The message transmitted to the readers is that such communities help to bring together both the producers and consumers of organic food in order to avoid the situation where food is produced anonymously.

Culinary discourse also carries gendered meanings. Although everyday cooking at home is usually done by women, cooking as a creative experience (as perceived in the media) is equally suitable for both men and women, or in some cases even more suitable for men. The discourse of organic food is definitely more connected to feminine values, hence to women: organic food is considered as more natural and more nature-friendly than regular food, which is also expressed on the linguistic level: the Estonian word mahe which designates organic food literally translates as 'mild' or 'gentle', and gentleness is considered a feminine quality in the Western world. It is noticeable that the propagators of organic food are mostly women. Feminine qualities like caring for others are in harmony with the ideas of organic food and natural lifestyle. Since women are mostly the caregivers for children and the family, those issues are more close to women's values and worldview. Women do the everyday cooking and therefore they are responsible for food, its quality and wholesomeness. Women are also more concerned with ecological issues on the grassroots level in their everyday practices. So, on the whole, they are the ones who prefer to buy organic food.

The women's important role as the consumers of the organic products is visible also on the economic level. The Estonia's best farmer of 2012, producer of organic milk products Arvo Veidenberg, has said that he owes his economic success to the young pregnant women whose fear of allergy motivates them to buy organic milk products (Reimer 2012). This claim refers to the women as the carers for the children: as allergy has become widespread in the society, the solution would be to change the diet which often means using organic products instead of conventionally grown goods. The news released in media emphasised the role of women as consumers of organic milk products, thus strengthening the gendered image of organic food.

Also, in popular Estonian Internet forums, such as Delfi (www.delfi.ee) or Perekool ('Family School', a forum dedicated to family life; www.perekool.ee) the issues about organic food and environment-friendly lifestyle have been discussed mostly by women. Sometimes very hot disputes about those issues develop in the forum, as the viewpoints of the two opposite parties (of those who do not support organic food and natural lifestyle versus the ones who do) collide. 
In conclusion, food in general (including organic food) is an important subject in contemporary Estonian media and a part of everyday news. It is also a much debated issue due to the problem of possibly unhealthy food additives. Organic food is represented by ambiguous evaluations: on the one hand it is described as pure and unspoiled, and on the other as expensive and unaffordable to most Estonians. Similarly, news texts about the pros and cons of organic food express different opinions, and the claims that organic food is not better than regular food are also heard. Media discourses also connect the theme of organic food to Estonian identity. In this way, the authentic, i.e. organic culinary behaviour is taken to reinforce it. This identity is also gendered as the majority of the consumers of organic food are women and feminine values are therefore an inseparable part of it.

\section{References}

Ferguson, Priscilla Parkhurst 2001. A cultural field in the making: Gastronomy in nineteenth-century France. In: L. R. Schehr \& A. S. Weiss (eds.) French food: on the table, on the page, and in French culture. New York \& London: Routledge, pp. 5-50.

Lien, Marianne Elizabeth 2004. The politics of food: An introduction. In: M. E. Lien \& B. Nerlich (eds.) The politics of food. Oxford \& New York: Berg Publishers, pp. 1-18.

Lockie, Stewart 2006. Capturing the sustainability agenda: Organic foods and media discourses on food scares, environment, genetic engineering, and health. Agriculture and Human Values 23, pp. 313-323.

Mahepõllumajandus Eestis 2011-2012. [Organic farming in Estonia 2011-2012.] Tallinn, Põllumajandusministeerium. http://www.organic-europe.net/fileadmin/documents/ country_information/estonia/vetemaa-mikk-2012-estonia-2011.pdf, last accessed on 1 August 2012.

Ninn, Eger 2012. Mahetoit on eesti inimeste jaoks liiga kallis. [Organic food is too expensive for Estonians.] http://www.tarbija24.ee/731112/mahetoit-on-eesti-inimeste-jaoksliiga-kallis/, last accessed on 1 August 2012.

Piigli, Marta 2007. Mahepõllumajanduse kuvand eesti meedias Maalehe ja Postimehe näitel 1997-2005. [The image of organic food in Estonian media (Maaleht and Postimees), 1997-2005.] Bakalaureusetöö. Tartu Ülikool, Sotsiaalteaduskond, Ajakirjanduse ja kommunikatsiooni osakond.

Pullerits, Priit 2011. Kõhu kaudu pankrotti - või helgesse tulevikku? [Consuming food: going bankrupt or towards a great future?] Postimees 22 October. http://www.postimees. ee/605700/kohu-kaudu-pankrotti-voi-helgesse-homsesse/, last accessed on 1 August 2012. 
Reimer, Andres 2012. Eesti parima talu piimaäri püsib tänu lapseootel naistele. [The best dairy farm in Estonia persists due to pregnant women.] Eesti Päevaleht 1 August.

Sarjas, Aive 2012. Viljandi toiduvõrgustik viib kauba otse talust tarbijani. [Food network in Viljandi takes products straight from the farm to the consumer.] Maaleht 9 January. http://www.maaleht.ee/news/uudised/eestiuudised/viljandi-toiduvorgustik-viib-kaubaotse-talust-tarbijani.d?id=63748282, last accessed on 15 October 2012.

Żarski, Waldemar 2013. Culinary identity as the determinant of cultural distinctiveness in Silesia and the Vilnius Region. In: L. Laineste \& D. Brzozowska \& W. Chłopicki (eds.) Estonia and Poland: Creativity and tradition in cultural communication, Vol. 2: Perspectives on national and regional identity. Tartu: ELM Scholarly Press, pp. 147-160. 